\title{
HAKIKAT MANUSIA MENURUT MUHAMMAD IQBAL
}

\author{
Yayah Nurmaliyah \\ yayahnurmaliah@uinjkt.ac.id \\ Universitas Islam Negeri Syarif Hidayatullah Jakarta
}

\begin{abstract}
Abstrak: Sejarah mencatat bahwa umat Islam pernah berada di posisi terdepan dalam peradaban dunia. Belakangan sebuah kenyataan juga tidak terbantahkan ketika umat Islam harus mengakui keunggulan komunitas lain dalam berbagai aspek kehidupan. Sebagai upaya mengembalikan kejayaan masa lalu, Muhammad Iqbal menyeru umat Islam untuk tidak terbuai dengan kegemilangan atau romantika masa lalu dan melarang untuk taqlid buta pada pemikiran masa lalu yang mengakibatkan hilangnya kreasi dan inovasi dalam menghadapi realitas perkembangan zaman. Muhammad Iqbal juga menyeru umat Islam untuk tidak bersikap apriori terhadap Barat, sebaliknya dapat memanfaatkannya dan meresponsnya dengan kritis. Hal ini disebabkan Muhammad Iqbal cukup lama mengikuti pendidikan di Barat yang dipenuhi oleh semangat penelaahan dan penelitian ilmu pengetahuan yang tinggi, sehingga ia dengan jelas melihat dan merasakan langsung bergantinya aktifitas ilmiyah dari Timur ke Barat. Hal ini cukup membuatnya kagum dan menginginkan umat Islam untuk mengikuti semangat Barat dalam melakukan kajian-kajian ilmiyah yang notebene pernah dilakukan sebelumnya. Muhammad Iqbal juga menyadari bahwa faktor tersebut di atas tidak akan bermanfaat apa-apa apabila umat Islam sendiri tidak memiliki semangat dan kemauan untuk berobah. Kemunduran umat Islam dewasa ini secara garis besar disebabkan oleh 2 faktor; internal dan eksternal. Kedua faktor itu harus dibenahi demi mengembalikan kecemerlangan masa lalu. Dengan mengutip QS. Al-Ra'd ayat 11, Muhammad Iqbal mencoba mengembangkan gagasannya mengenai khudi yang notabene merupakan hakikat dari kemanusiaan itu sendiri. Menurutnya moralitas suatu bangsa ditentukan oleh pandangan masyarakatnya mengenai khudi ini, dan segala sesuatu di alam ini memiliki khudinya sendiri-sendiri. Setiap khudi akan bergerak maju sehingga mencapai titik perkembangannya masing-masing.
\end{abstract}

Kata Kunci: Hakikat Manusia, Muhammad Iqbal, Khudi

\section{A. Pendahuluan}

Bangsa yang besar adalah bangsa yang memiliki tokoh-tokoh besar dengan pemikiran yang besar pula. Keberadaan para tokoh membuat sebuah bangsa berjalan terarah sehingga hal-hal yang sekiranya dapat mengganggu dapat diminimalisir atau diatasi lebih dini. Semakin para tokoh mendapat tempat, maka tentu saja jaminan keberlangsungan fungsi tersebut dapat direalisasikan.

Potret sejarah umat Islam juga mengindikasikan hal yang sama. Ajaran Islam yang progresif, diiringi dengan kesempatan luas dan apresiasi yang tinggi dari para khalifah
Abbasiyah-seperti Khalifah alMakmun (813-833H), Khalifah Harun al-Rasyid $(786-809 \mathrm{H})$, dan Khalifah al-Manshur (754-775H) membuat dinasti ini dipandang sebagai dinasti yang maju dalam ilmu pengetahuan. Penghargaan yang diberikan atas pikiran-pikiran besar dan karya-karya besar melahirkan motivasi tersendiri kepada para tokoh untuk senantiasa continuosly berbuat. Belakangan disebabkan oleh beberapa hal, semangat ilmiyah ini berkurang. Beruntungnya kendatipun menurun, spirit ini tetap hidup meskipun dinasti ini harus menerima takdirnya dengan ditaklukkannya Baghdad oleh Hulagu 
Khan pada tahun 1258. Belahan dunia Islam tidak berhenti melahirkan tokohtokoh besar dengan karya-karya besar yang salah satunya muncul dan lahir dari rahim benua Asia yaitu Muhammad Iqbal.

\section{B. BIOGRAFI MUHAMMAD IQBAL}

Muhammad Iqbal lahir di Sialkot, Punjab-sekarang termasuk wilayah Pakistan - tanggal 09 November 1877, dan wafat di puncak kejayaan dan kemasyhurannya pada dini hari tanggal 21 April 1938 di Lahore (Ihsan Ali Fauzi dan Nurul Agustina, 1992:17). Nama Muhammad Iqbal sering juga diawali dengan sir atau allama. Gelar sir diberikan oleh Pemerintah Inggris tahun 1922 karena ketenarannya yang luar biasa, sementara gelar allama adalah penghormatan muslim Pakistan dan Dunia Islam atas kepakarannya di bidang agama (Republika, 2017:15).

Keluarga Iqbal berasal dari kasta Brahma Kashmir yang telah masuk Islam beberapa generasi sebelumnya. Ayahnya Syekh Noor Muhammad (w. 1930) adalah seorang sufi yang pekerjaan sehari-harinya adalah sebagai pedagang kecil. Ada yang mengatakan bahwa pekerjaannya adalah penjahit dan tidak memiliki pendidikan formal (Republika, 2017:15). Kemungkinan besar ia adalah seorang buta huruf, namun ia adalah seorang muslim yang taat beragama dan sangat keras mendorong anaknya agar mampu menghafal alQuran dengan baik. Peranan ayahnya ini begitu berpengaruh dalam kehidupan Iqbal secara menyeluruh (Annemarie Schimmel, 1963:35). Demikian pula dengan ibunya, Imam Bibi, sosok perempuan yang sopan dan rendah hati yang selalu fokus memperhatikan pendidikan agama bagi anaknya.

Keteguhan hati dan kedisiplinan sang ayah dalam menjalankan tasawuf merupakan buah dari pengajaran yang diperoleh dari kakek Muhammad Iqbal yaitu Muhammad Rafiq, seorang tokoh sufi terpandang yang berasal dari Kashmir dan kemudian berimigrasi ke Sialkot, Punjab. Kuatnya pengaruh pengajaran keagamaan yang diperoleh Iqbal dari kedua orang tuanya diungkapkan dalam sebuah syair sebagai berikut:

Dalam asuhanmu

Ku gapai bintang-bintang

Rumahu kebanggaan moyang

Hidupmu lempeng keemasan

dalam buku alam semesta

Dan panutan dalam agama dan

dunia

Iqbal memperoleh pendidikan

masa kanak-kanaknya di bawah bimbingan ayahnya. Pada usia sekolah, Iqbal dimasukkan ke sebuah maktab (madrasah) untuk belajar al-Quran. Setelah menyelesaikannya, Iqbal kemudian melanjutkan studinya di Scottish Mission School di Sialkot, Punjab. Disinilah potensi intelektualnya mulai berkembang di bawah bimbingan intensif Mir Hassan, seorang guru dan sastrawan yang sangat inspiratif dan sangat mengerti akan potensi kecerdasan serta daya imajinasi Iqbal. Ia juga mengajarkan Iqbal cara menggubah puisi klasik Urdu dan Persia. Tokoh yang juga sahabat karib ayahnya ini kelak menjelma menjadi pribadi yang sangat berpengaruh dalam pembentukan intelektualitas dan kepribadian Iqbal. Pengakuan atas peran gurunya tersebut dituliskan Iqbal dalam syairnya sebagai berikut: 
90 Majalah Ilmu Pengetahuan dan Pemikiran Keagamaan Tajdid,

Vol. 21, No. 1, Juli 2018

berkah

Cahaya dari keluarga Ali penuh

Pintu gerbangnya dibersihkan senantiasa bagiku Ka'bah

Nafasnya menumbuhkan tunas keinginanku

Penuh gairah hingga menjadi kuntum bunga yang merekah indah

Daya kritis tumbuh dalam diriku oleh cahayanya yang ramah.

Selain Mir Hassan, Iqbal juga mendapatkan bimbingan untuk menggubah puisi Urdu dari Nawab Mirza Khan Dagh. Pada masa itu para penyair muda mengirimkan puisinya kepada Dagh untuk dikoreksi. Hal yang sama juga dilakukan Iqbal. Ia tidak mau kehilangan momentum untuk memperoleh koreksian dari sang maestro. Sayangnya hal ini tidak berlangsung lama, dimana begitu Dagh mengenal bakat puisi Iqbal, ia malah meminta Iqbal untuk tidak lagi mengirimkan karyanya untuk dikoreksi. Bisajadi hal ini disebabkan karena dalam pandangan Dagh, Iqbal dengan kemampuan yang dimilikinya tidak lagi membutuhkan koreksian darinya. Iqbal dianggap mampu menggubah puisinya secara mandiri.

Nama Iqbal mulai dilirik mata publik ketika ia melantunkan puisinya yang berjudul Nala-i-Yatim (Tangisan Anak Yatim) yang disampaikan pada acara pertemuan tahunan sastrawan Anjuman-I-Himayat-I-Islam di Lahore. Iqbal selalu menyampaikan perasaan dan ide pemikirannya dalam bidang politik dan sosial keagamaannya melalui puisi. Hal ini disebabkan karena menurutnya puisi adalah sarana yang tepat untuk menyampaikan pikiran dan perasaan secara halus, tetapi tajam. Dalam waktu yang singkat, Iqbal dapat membangun reputasinya dalam dunia sastra hingga beberapa sajaknya dimuat di berbagai jurnal waktu itu.

Setelah

menamatkan pendidikan di Scottish, Iqbal melanjutkan pendidikannya ke Government College Lahore tahun 1895. Ketika belajar di Government College inilah Iqbal bertemu dengan Sir Thomas Arnold, seorang orientalis asal Inggris yang mengajarkan Iqbal tentang Filsafat Islam dan selalu memotivasinya untuk melanjutkan petualangan intelektualnya ke Eropa. Melalui Sir Thomas Arnold untuk pertama kali ia melihat dan berinteraksi langsung dengan peradaban Barat, khususnya ketika belajar di Inggris dan Jerman. Antara keduanya terjalin hubungan yang begitu dekat melebihi hubungan guru dan murid, sebagaimana yang tertuang dalam kumpulan sajaknya Bang-IDara (Khalifat Abdul Karim, 1991:16).

Dua tokoh dari dua dunia berbeda di atas-Timur dan Baratkelak membekali Iqbal dalam menghadapi pengalaman intelektualnya. Mir Hassan memberikan sentuhan spiritual Timur sedangkan Sir Thomas Arnold membekalinya dengan sentuhan rasional Barat. Pemikiran kedua tokoh ini kelak berpadu dalam pemikiran keislaman Iqbal. Tokoh lain yang sangat dikagumi dan diakuinya sebagai guru spiritualnya adalah Maulana Jalaluddin Rumi (w. 1273), seorang sufi penyair yang termasyhur asal Konya, Turki. Syair dan prosanya senantiasa dihubungkannya dengan sang Maulana, seperti tampak dalam sajak Prolog di Bumi yang terdapat dalam Javid Nameh, Iqbal menggambarkan pertemuannya dengan Jalaluddin Rumi dan Nietzsche yang 
terjadi di alam khayali dalam safari spiritualnya di luar langit (Muhammad Iqbal. 1987:20).

\section{Setelah} menamatkan pendidikan di Government College pada tahun 1905, Iqbal melanjutkan studinya ke Trinity College Universitas Cambridge, London. Disana ia memperdalam filsafat moral di bawah bimbingan Mc. Taggart dan James Ward. Karir studi Iqbal kemudian dilanjutkan di Universitas Munich dan disinilah ia memperoleh gelar $\mathrm{PhD}$ dengan disertasi yang berjudul The Development of Metaphisic in Persia pada tahun 1907 di bawah bimbingan Prof. F. Hammel (Djohan Effendi, 1986:7). Disertasi ini kemudian diterbitkan di London dan dipersembahkan kepada Sir Thomas Arnold sebagai kenang-kenangan. Setelah itu Iqbal kembali ke London untuk mempelajari ilmu hukum dan lulus dalam bidang keadvokatan (Hasyimsyah Nasution, 1990:182).

Selama tiga tahun di Eropa, Iqbal banyak membaca buku di Perpustakaan Cambridge dan Munich serta mendiskusikan berbagai persoalan dengan para sarjana dan cendekiawan Eropa yang pada akhirnya sangat menunjang perkembangan pemikirannya (SA. Vahid, 1990:13). Di samping itu Iqbal juga sering memberikan ceramah dalam berbagai kesempatan tentang Islam. Isi ceramahnya itu dipublikasikan dalam berbagai media. Setelah menyaksikan langsung dan mengkaji kebudayaan Barat, ia bersikap kritis dan tidak terpesona oleh gemerlap dan daya pikat kebudayaan tersebut. Dimensi positif dia ambil, negatifnya ditinggalkan. Iqbal tetap fokus pada budaya dan kepercayaannya. Hal ini kemudian dalam banyak kesempatan ditunjukkan Iqbal melalui gubahan sajak dan syairnya.

\section{KARYA-KARYA}

Muhammad Iqbal adalah sosok ilmuan dan budayawan yang produktif dalam menghasilkan karya-karya ilmiyah. Beberapa yang dapat disebutkan adalah sebagai berikut:

1. Shikwa dan Jawab Shikwa. Karya ini merupakan himpunan sajak Iqbal yang pertama diterbitkan dan diterjemahkan oleh AJ. Arberry ke dalam bahasa Inggris, Complaint and Answer, diterbitkan di Lahore tahun 1955.

2. Asrar-I-Khudi. Karya ini diterjemahkan oleh RA. Nicholson ke dalam bahasa Inggris, The Secrets of Self, diterbitkan di London tahun 1920.

3. Rumuz-I-Bekhudi. Karya ini dierjemahkan oleh AJ. Arberry ke dalam bahasa Inggris, The Mysteries of The Selfless, diterbitkan di London tahun 1952.

4. Payam-I-Masyriq. Karya ini diterjemahkan oleh Abdul Wahhab Azzam ke dalam bahasa Arab dan diterbitkan di Karachi tahun 1951. Abdul Hadi WM juga menerjemahkannya ke dalam bahasa Indonesia, Pesan dari Timur, melalui terjemahan bahasa Inggris dari M. Hadi Husain, Message from East, 1977.

5. Bang-I-Dara.

6. Zabur-I-Azam. Karya ini diterjemahkan oleh AJ. Arberry ke dalam bahasa Inggris, The 
Persian Psalm, diterbitkan di Lahore tahun 1948.

7. Javid Nameh. Karya ini diterjemahkan oleh M. Ahmed, Pilgrimage of Eternity, diterbitkan di Lahore tahun 1964.

8. Musafir.

9. Bal-I-Jibril. Karya ini diterjemahkan oleh Bahrum Rangkuti yang digabungkan ke dalam terjemahan Asrar-IKhudi.

10. Pas Chi Bayad ay Aqwam-ISharq. Karya ini diterjemahkan oleh Abdul Hadi WM ke dalam bahasa Indonesia, Kumpulan Sajak Iqbal; Pesan kepada Bangsa-Bangsa Timur.

11. Zarb-I-Kalim. Karya ini diterjemahkan oleh Abdul Wahhab Azzam ke dalam bahasa Arab dan diterbitkan di Kairo tahun 1952.

12. Armaghan-I-Hijaz. Karya ini diterjemahkan oleh Muhammad Nabhan Husein ke dalam bahasa Indonesia, Hadiah dari Hijaz, 1980.

13. The Development of Metapysic in Persia. Karya ini merupakan disertasi doktoral Muhammad Iqbal di Munich University, Jerman.

14. The Recontruction of Religious Thought in Islam. Karya ini diterjemahkan dua kali ke dalam bahasa Indonesia yaitu masing-masing oleh Osman Ralibi, diterbitkan oleh Bulan Bintang tahun 1966, dan tim yang terdiri dari Taufiq Ismail, Goenawan Muhammad, dan Ali Audah juga pada tahun 1966.

\section{PERJALANAN KARIR}

Muhammad Iqbal adalah sosok pembelajar yang tidak pernah berhenti menambah pengetahuannya. Setelah menyelesaikan studi di Scottish Mission College dan Government College, Iqbal dengan dorongan dan dukungan dari Sir Thomas Arnold, melanjutkan karir intelektualnya ke Barat. Pengembaraan Iqbal di Eropa berakhir pada 1908. Sebelum pergi ke Eropa, ia lebih dahulu telah mengajar di Oriental College dan Government College di Lahore. Karirnya dalam dunia pendidikan dilanjutkan setelah kembali dari Eropa (Djohan Effendi, 1986:7). Ia sempat menjabat beberapa tahun sebagai Dekan Fakultas KajianKajian Ketimuran dan Ketua Jurusan Kajian-Kajian Filosofis. Namun Iqbal hanya bertahan satu setengah tahun mengajar di sekolah ini. Ia mengundurkan diri dengan alasan tidak dapat berdedikasi pada Pemerintah Inggris (Abdul Wahhab Azam, 1980:28). Selain alasan tersebut, ia merasakan kebebasannya terbatasi dalam berekspresi dan berfikir karena kegiatan pendidikan diawasi dengan ketat oleh Pemerintah Inggris. Namun meskipun telah mengundurkan diri, hubungannya dengan Pemerintah Inggris tidaklah terputus. Selain itu ia juga selalu menjalin hubungan dengan Islamic College dan Universitas Milla Lahore. Setelah mengundurkan diri dari jabatannya di Government College, Iqbal beralih profesi sebagai advokat yang dijalaninya empat tahun terakhir sebelum wafatnya.

Profesi sebagai pengacara inilah kelihatannya yang membawa Iqbal ke dalam dunia pergerakan politik praktis di negeranya. Karirnya dalam pergerakan politik ini sempat mengantarkannya menjadi Presiden 
Liga Muslim India. Ketika Konfrensi tahunan Liga Muslim di Allahabad tanggal 29 Desember 1939, Iqbal adalah orang pertama yang menyerukan agar India dibagi dua bagian sehingga kaum muslimin memiliki sebuah negara otonom, dan menurutnya hal ini tidak bertentangan dengan persatuan umat Islam dan PanIslamis. Dengan pemikiran tersebut, ia kemudian dikenal dan dijuluki sebagai Bapak Pakistan (Harun Nasution, 1975:194).

Disamping menjadi advokat, Iqbal juga sering diundang oleh berbagai lembaga pendidikan untuk memberikan ceramah. Pada tahun 1928, ia diundang memberikan ceramah di Madras, Hyderabad, dan Aligarh. Ceramah-ceramahnya kemudian dihimpun dalam sebuah buku berjudul The Recontruction of Religious Thought in Islam yang sekaligus menjadi magnum opus-nya.

Seperti telah diulas di atas, kedudukan Iqbal di Liga Muslim memberikan peluang baginya untuk mencetuskan ide-ide pemikirannya. Dalam konfrensi Meja Bundar, ia menjadi anggota dalam komisi yang meneliti masalah perbaikan pendidikan di India. Dalam kedudukannya ini ia menyusun berbagai proyek baru, termasuk mengusulkan tentang kajian Yurisprudensi Islam dan Bimbingan Pengkajian al-Quran. Iqbal juga mengusahakan berdirinya sebuah proyek akademis, yaitu Lembaga Penelitian Tingkat Lanjut bagi para sarjana muslim untuk menekuni bidang keislaman klasik dan ilmu sosial kontemporer. Atas bantuan seorang dermawan, proyek ini dapat terwujud dengan berdirinya Jama'at al-Islami, dan diterbitkannya Tarjuman al-Quran oleh Abu A'la al-Maududi, seorang sarjana muslim potensial yang diundang Iqbal untuk membantu mewujudkan proyeknya tersebut. Adapun sumbangan terbesar Iqbal sendiri di bidang pendidikan dan pengajaran ialah Filsafat Kepribadiannya yang ia terapkan pada pendidikan, pengajaran, dan seni dalam kebanyakan sajak-sajaknya (Abdul Wahhab Azam, 1980:23).

Sejak 1935 kesehatan Iqbal menurun drastis akibat penyakit kencing manis yang dideritanya. Informasi lain mengatakan bahwa Iqbal menderita sakit tenggorokan misterius paska muhibahnya ke Spanyol dan Afghanistan (Republika, 2017:15). Fisiknya terus melemah dan akhirnya pada tanggal 21 April 1938, sang pujangga menghembuskan nafasnya yang terakhir. Ia dimakamkan di Hazuri Bagh, sebuah taman tertutup yang terletak di pintu masuk Masjid Badshahi dan Benteng Lahore. Beberapa jam sebelum maut mendatanginya, ia masih sempat membacakan sebuah syair kuatren Persia kepada Hassan Akhtar, seorang pengagumnya. Kemungkinan syair tersebut telah digubah beberapa bulan sebelumnya. Kuatren ini berisi isyarat akan pentingnya posisi penulis dalam sejarah:

Tembang perpisahan akan terdengar atau tidak

berdesir atau tidak

Semilir angin Hijaz akan Hari-hari akhir si Faqir akan segera tiba

Seorang bijak lain boleh jadi akan datang atau tidak

Muhammad Iqbal meninggal dunia dalam usia 65 tahun dengan meninggalkan banyak karya. Produktifitasnya dalam dunia akademik tidak pernah berhenti hingga 
akhir hayatnya. Ia selalu diingat oleh rakyat Pakistan dan dianggap sebagai pendiri ideologi negara. Namanya diabadikan pada banyak lembaga publik seperti; Allama Iqbal Campus University Punjab di Lahore, Allama Iqbal Medical College di Lahore, Iqbal Stadium di Faisalabad, Allama Iqbal Open University di Pakistan, Allama Iqbal International Airport di Lahore, Allama Iqbal Hall di Universitas Aligarh, dll (Republika, 2017:15).

\section{E. URGENSI KHUDI MENURUT MUHAMMAD IQBAL}

Secara etimologi khudi menurut Iqbal berarti pribadi, ego atau individualitas yang merupakan suatu kesatuan yang riil atau nyata. Khudi adalah pusat dan merupakan suatu iradah kreatif yang terarah secara rasional yang menjelaskan bahwa hidup bukanlah suatu arus tak berbentuk, melainkan suatu prinsip kesatuan yang bersifat mengatur. Suatu kegiatan sintesis yang melingkupi serta memusatkan kecenderungankecenderungan yang bercerai-berai dari organisme yang hidup ke arah suatu tujuan yang konstruktif (Muhammad Iqbal, 1981:60). Iqbal menerangkan bahwa khudi merupakan pusat dan landasan dari keseluruhan kehidupan. Hal ini tercantum dalam beberapa syairnya dalam Asrar- $i$ Khudi sebagai berikut: dari khudi

Bentuk kejadian ialah akibat Apa saja yang kau lihat adalah rahasia khudi

Dijelmakannya alam cita dan pikiran murni

Ratusan alam terlingkup dalam intisarinya
Menjelmakan dirimu

melahirkan yang nafi khudimu

Oleh khudi tersemailah di

luasan dunia bibit kemauan

Mulanya disangkanya dirinya lain dari dirinya

Dijelmakan dalam dirinya

bentuk-bentuk lain

Agar memperkembang biak

nikmat pertarungan

lenganmu

Dijatuhkannya tenaga sendiri

Agar disadarinya tenaganya

Tipuan pada dirinya sendiri ialah intisari kehidupan

Sesungguhnya khudi menurut Iqbal tidak hanya terbatas pada manusia. Tetapi ada pada setiap wujud dan bertempat dalam alam ini tergantung pada tingkat khudi yang bersangkutan. Khudi akan terus bergerak baik dalam proses asosiasi dan interaksinya di alam semesta ini sehingga menaiki tangga keberadaan ke titik perkembangan manusia yang tertinggi ketika menjadi pribadi (Miss Luce-Claude Maitre, 1989:13).

Penggambaran perkembangan khudi dari keadaannya yang sederhana menuju keadaan yang lebih kompleks dan sempurna, dapat dilihat pada perkembangan organisme yang hidup. Benih tumbuh-tumbuhan berkembang menjadi kecambah yang berakar kecil dan berdaun kecil, kemudian batangnya tambah besar serta akar dan daunnya bertambah banyak jumlahnya yang akhirnya menjadi besar pula, berbunga dan berbuah. Demikian pula garis perkembangan pada manusia dan binatang. Pada materi perkembangan itu lebih tampak sebagai permanensi.

Perkembangan dan kesempurnaan khudi pada setiap 
organisme hidup akan terus mengalami tingkatan yang berbeda tergantung kepada kerja kerasnya di alam semesta dengan melakukan serangkaian tindakan, realisasi diri untuk mewujudkan cita-cita dari berbagai lapangan kehidupan berdasarkan aspirasi, gagasan dan kepercayaan agama sendiri. Pandangan di atas diungkapkan Iqbal dalam matsnawinya sebagai berikut:

Segala sesuatu berupaya mengungkapkan diri

Setiap zarrah mati demi

keagungan

Tanpa mengungkapkan diri hidup ini bukan hidup

Dengan pribadi sempurnanya insan jadi seolah Tuhan

Dengan kekuatan pribadinya jerami berubah jadi gunung

Bila gunung lemah ia akan kembali jadi tumpukan jerami jagad raya

Pribadi sajalah yang hakiki di semata

Yang lain hanyalah khayalan

Konsep khudi memang cukup sukar dipahami sehingga banyak menimbulkan spekulasi, untuk itu Iqbal mencoba menjelaskannya dengan membedakan antara arti metafisis dan etisnya. Secara metafisis kata khudi dipakai dalam arti perasaan tentang $A k u$ yang tidak dapat dilukiskan dan merupakan dasar dari keunikan tiap individu (CA. Qadir, 1998:177). Dari segi etika, kata khudi berarti mengandalkan diri sendiri, harga diri, percaya diri sendiri, mempertahankan diri, bahkan menonjolkan diri, apabila itu diperlukan demi kepentingan hidup serta kekuatan untuk tetap membela kebenaran, keadilan, kewajiban bahkan dalam menghadapi maut sekalipun.
Prilaku seperti itu adalah prilaku moral karena mengintegrasikan kekuatankekuatan ego yang akan memperkuatnya. Jauh berbeda dengan kekuatan-kekuatan yang menyebabkan disintegrasi dan perpecahan. Secara praktis ego metafisis adalah pendukung dua hak utama, yakni hak hidup dan hak untuk bebas, seperti ditetapkan oleh Hukum Tuhan.

Terkait dengan hal tersebut menurut Iqbal, khudi dapat dijelaskan dengan melihat beberapa kharakteristik yang dimilikinya antara lain: Pertama, khudi manusia adalah ego yang sendiri-sendiri, sebagaimana yang dikatakan oleh Iqbal,"only that trully exist which can say I am", yang pantas dinyatakan ada dalam arti ini aku, yaitu tingkat atau derajat keakuan yang menentukan suatu benda dalam skala realitas (Muhammad Iqbal, 1981:56).

Kedua, ego menyatakan dirinya sebagai satu kesatuan keadaan mental (the unity of mental state). Keadaan mental ini tidak berdiri sendiri melainkan terjadi dan memberikan arti satu sama lain dalam bentuk tingkatan dari satu keseluruhan yang kompleks sebagai suatu hal yang disebut pikiran (mind). Kesatuan organis dari keadaan mental ini menunjukkan hubungan istimewa yang secara fundamental. Berbeda dengan kesatuan benda material yang dapat berdiri sendiri dalam isolasi satu sama lainnya.

Ketiga, ego tidak terkait dengan ruang sebagaimana halnya ragawi. Peristiwa mental dan fisik memang berada dalam jarak waktu, tetapi jarak waktu ego secara fundamental berbeda dengan jarak waktu secara fisik. Perlangsungan waktu peristiwa fisik terbentang dalam ruang sebagai suatu fakta yang terjadi kini, sementara perlangsungan waktu ego dipusatkan 
dan dihubungkan masa kini dan masa depan secara unik. Pembentukan suatu peristiwa fisik memperllihatkan tandatanda tertentu akan peristiwa masa kini yang menunjukkan bahwa peristiwa fisik tersebut melalui perlangsungan waktu, tetapi tanda-tanda ini hanya bersifat perlambang belaka dan bukan perlangsungan waktu itu sendiri. Perlangsungan waktu sebenarnya hanya dimiliki oleh ego.

Karakteristik ego yang keempat adalah kesendirian esensial dari ego yang menunjukkan keunikan. Apa yang dirasakan dan dipikirkan oleh ego adalah miliknya sendiri. Kesenangan, kepedihan, dan kehendak, adalah khusus milik saya, kata Iqbal. Begitu juga dengan kebencian, cinta, pertimbangan dan keputusan. Keseluruhan kondisi ini merupakan bagian dari diri. Disinilah lalu muncul persoalan psikologis yang menyebabkan seseorang menyebut kata " $A k u$ " (Muhammad Iqbal, 1981:100).

Cara pandang Iqbal ini menolak pandangan kaum Jabariyah yang berpendapat bahwa perbuatan seseorang adalah perbuatan Tuhan. Manusia hanya diibaratkan seperti dalang yang tidak dapat bergerak kecuali bila digerakkan oleh dalangnya. Ia tidak punya kuasa/otoritas untuk melakukan apa yang diinginkan. Iqbal berpendapat sebaliknya, dan hanya dengan demikian menurutnya, seseorang dapat bertanggungjawab atas perbuatannya sendiri, tidak mengatasnamakan Tuhan atau sesuatu yang lain.

Berbicara

mengenai

kesempurnaan khudi, menurut Iqbal khudi manusia belum dapat mencapai suatu kesempurnaannya kecuali jika ia berusaha mendekatkan diri kepada Ego
Mutlak (Tuhan), tetapi bukan berarti akhirnya ia hanyut terserap ke dalam Tuhan, melainkan sebaliknya ia harus menyerap (sifat Tuhan) ke dalam dirinya. Selain itu ia juga harus mampu menyerap dunia materi, yaitu dengan cara menguasainya. Hal tersebut dijelaskan Iqbal dalam makalahnya yang dilampirkan dalam pendahuluan terjemahan Asrar-i-Khudi oleh Nicholson sebagai berikut:

The greater his distance from God, the less his individuality. He who comes nearest to God is the completest person. No that he is finally absorbed in God. On the contrary, he absorbs God into himself. The true person not only absorbs the world of matter; by mastering it he absorbs God Him self into his ego (Danusiri, 1996:135).

Penguasaan manusia terhadap lingkungan (dunia materi) mengantarkannya untuk mencapai tingkat kehendak bebas melalui pendekatannya kepada Ego Mutlak. Selanjutnya ia akan memperoleh kebebasan yang sempurna.

Sebagai seorang humanis, Iqbal lebih jauh mendefinisikan khudi dengan meyakini bahwa setiap manusia mempunyai daya untuk mencapai tingkat keberadaan yang sempurna dan memiliki daya kreatif. Manusia dengan segala keberadaannya mampu mengembangkan suatu daya cipta. Dengan dayanya itu ia dapat mempertahankan dan memperkuat khudinya, hingga ia sanggup menyadari eksistensi dirinya dan akhirnya mampu mengarahkan tujuannya untuk mencapai kesempurnaan dan turut memperindah kehidupan dunia ini.

Penjelasan tentang makna khudi di atas mengantarkan Iqbal pada pendangannya mengenai tujuan 
pendidikan dan sosial budaya. Bagi Iqbal tujuan akhir pendidikan demikian pula tujuan paling tinggi dari segala usaha dan gerakan sosial budaya hendaknya memperkokoh dan memperkuat khudi dari semua pribadi sehingga mereka dapat menyadari segala kemungkinan yang dapat saja menimpa mereka dalam kehidupan.

\section{F. KHUDI SEBAGAI PRASYARAT KEMAJUAN}

Pada hakekatnya khudi manusia menurut Iqbal memiliki tingkat realitas tertinggi di antara makhluk Tuhan lainnya. Oleh sebab itu impuls kreatif manusia dapat mengembangkan khudinya pada derajat yang lebih tinggi. Jika kemerdekaan khudi yang nampak pada kegiatan perbuatannya dirintangi oleh lingkungannya, maka ia berkuasa mewujudkan dirinya pada khudi-nya sendiri.

Bagi Iqbal untuk mengembangkan khudi, aktifitas khudi haruslah merupakan proses yang terus maju ke dapan dengan selalu mengadakan asimilasi, aksi dan reaksi dengan lingkungan atau khudi-khudi yang lain. Dimana esensinya untuk terus-menerus menciptakan cita-cita dan tujuan-tujuan yang baru dan segar dalam kehidupannya.

Pernyataan di atas mengandung arti bahwa manusia haruslah ikut ambil bagian dalam aspirasi alam semesta di sekitarnya dan untuk memberi bentuk baik pada takdirnya sendiri maupun takdir alam semesta. Prosesnya adalah dengan cara, suatu kali individu menyesuaikan dirinya dengan kekuatan-kekuatan alam semesta dan di lain waktu, individu menggunakan seluruh tenaganya untuk mengendalikan kekuatan-kekuatan alam semesta demi cita-cita dan tujuannya sendiri. Pada saat terjadi kontak dinamis antara alam semesta dengan lingkungannya, maka akan terciptalah keabadian khudi.

Berbicara mengenai hubungan khudi dengan lingkungannya, dalam hal ini Iqbal berpandangan dinamis terhadap proses penyesuaian diri. Dinamika itu dianggapnya berjalan secara konstan antara individu dengan lingkungannya. Iqbal mengemukakan bahwa "sudah suratan nasib" manusia harus merobah dirinya terhadap berbagai kekuatan dan daya alam semesta. Manusia harus mencurahkan segala energinya untuk memanfaatkan daya kekuatan alam semesta itu bagi harapan dan tujuan dirinya sendiri. Dalam perobahan yang begitu cepat Tuhan pun bertindak sebagai kawan kerjanya, asalkan manusia berani mencoba mengambil inisiatif. Iqbal kemudian mengutip firman Allah sebagai berikut:

Sesungguhnya Allah tidak akan merobah keadaan suatu kaum, sehingga mereka berusaha untuk merobah keadaannya sendiri (QS. AlRa'd ayat 11).

Ayat tersebut menyiratkan bahwa apabila manusia tidak kreatif berarti ia tidak mau merobah dirinya. Apabila ia tidak berkeinginan merobah dirinya, maka ruh yang ada dalam dirinya akan mengeras menjadi batu dan dia pun merosot turun ke tingkat benda mati. Manusia seperti ini tidak akan mungkin menghasilkan kebaikan. Karena itu kemerdekaan adalah syarat kebaikan. Tetapi membiarkannya bangkit suatu khudi terbatas yang memiliki kemampuan memilih, sesudah mempertimbangkan berbagai nilai dari berbagai cara bertindak yang terbuka padanya sendiri, merupakan resiko yang sangat besar. Sebab 
98 Majalah Ilmu Pengetahuan dan Pemikiran Keagamaan Tajdid,

Vol. 21, No. 1, Juli 2018

kemerdekaan memilih yang baik, juga mencakup memilih lawan yang baik. Bahwa Tuhan mengambil resiko ini bagi manusia, memperlihatkan kepercayaan-Nya pada manusia (Muhammad Iqbal, 1981:85).

Demikianlah uniknya manusia menurut Iqbal, sekalipun ia diciptakan, namun tetap unik sebagaimana uniknya Tuhan. Bedanya terletak pada fakta bahwa manusia menjadi makhluk yang unik jika dibandingkan dengan makhluk apapun di alam semesta. Manusia menyertai Tuhan dalam kerja menciptakan, yaitu sebagai pencipta kedua. Terkait hal ini Iqbal menuliskannya dalam syair sebagai berikut:

\section{Tuhan mendeskriditkan}

Keadaannya sudah seperti ini

Usahakanlah engkau punya

usul lagi tentang ini

Manusia menjawab:

Tidak diragukan lagi

Keadaan memang seperti ini

Tapi harus seperti itu

Bangunlah pribadimu demikian hebat dan jayanya

Sehingga sebelum Tuhan menentukan takdir-Nya bagimu

Apakah kehendak-Nya yang sebenarnya

Tuhan menciptakan dunia dan indah

Manusia membuatnya lebih

Apakah manusia ditakdirkan untuk menjadi saingan Tuhan?

Syair tersebut merefleksikan pemikiran bebas Iqbal yang sadar dan mengakui bahwa anugerah kebebasan manusia harus difungsikan dan bahwa fungsionalisasi kebebasan ini merupakan manifestasi dari rasa tanggungjawab manusia sebagai khalifah Tuhan di muka bumi untuk terus mewujudkan kebaikan bagi kehidupannya.

Perkembangan khudi menurut Iqbal adalah suatu proses kreatif. Dalam hal ini manusia harus memainkan peranan yang aktif, melakukan aksi dan reaksi yang bertujuan baik untuk lingkungannya. Jadi proses ini bukanlah kejadian dimana individu hanya tinggal menyesuaikan diri secara pasif terhadap lingkungan yang statis (Muhammad Iqbal, 1981:86). Individu harus tetap dapat memelihara suatu keadaan yang tegang (stabil) dengan lingkungannya yang akan menyebabkan khudi-nya hidup dinamis. Tegangan khudi itu bukanlah hal yang sembarangan yang dapat memorosotkan dan menghanyutkan khudi. Tetapi tegangan itu bersifat memimpin dan mengarahkan lingkungan. Khudi dalam hal ini benarbenar sebagai subyek yang memimpin lingkungan dan bukan sebagai objek yang ditundukkan lingkungannya.

Pandangan bahwa khudi merupakan sebuah tegangan mnunjukkan bahwa khudi yang sebenarnya bukanlah suatu benda, tetapi perbuatan atau aktifitas. Dalam hal ini Iqbal mengatakan:

Thus my real personality is not thing, it is an act. My experience is only a series of act, mutually refering to one another, and held togedher by the unity of a directive purpose. You cannot perceive me like a thing in space, or a set of experience in temporal order; you must interpret, understand and appreciate me in my judgment, in my will-attitudes, aims and aspiration (Muhammad Iqbal, 1981:90).

Kutipan di atas menjelaskan bahwa khudi bukanlah bersifat benda, 
tetapi ia adalah aktifitas atau perbuatan. Pengalaman adalah suatu rentetan dari aktifitas-aktifitas yang saling mengarahkan, menunjuki satu sama lain yang dipersatukan oleh kesatuan dari satu tujuan terpimpin. Seluruh realitas saya, kata Iqbal, terletak dalam sikap terpimpin saya. Anda tidak dapat melihat saya sebagai benda dalam ruang, atau rangkaian pengalaman dalam rentetan waktu tetapi anda harus memahami dan menilai saya menurut pertimbangan saya, sikap kehendak, tujuan-tujuan dan aspirasi saya (Muhammad Iqbal, 1981:99).

Keterangan tersebut jelas menggambarkan nada optimis Iqbal memandang manusia sebagai kumpulan perbuatan yang diakibatkan dari tegangan-tegangan dalam berinteraksi dengan lingkungannya. Tegangan-tegangan tersebut dapat lestari bila dipelihara. Selama tidak menghiraukan kehidupan sosial dan politik sehari-hari, dimana penafsiran diri sepenuhnya lari dari kelahiriahan ke kebatinan, dan dari eksetoris ke esoteris, maka tujuan tersebut tidak akan tercapai.

\section{G. KESIMPULAN}

Demikianlah beberapa percikan pemikiran Iqbal yang berkenaan dengan khudi sebagai instrumen terpenting dalam diri setiap manusia. Khudi memiliki potensi yang luar biasa untuk memposisikan manusia pada posisi yang seharusnya yaitu sebagai "pencipta". Perasaan gelisah yang selalu menggelayuti Iqbal ketika melihat ketidakberdayaan kaum muslimin vis a vis superioritas Barat tidak berhenti hanya dalam ratapan, namun dengan sebuah solusi kongkrit agar umat Islam sadar dengan keberadaan dan potensi khudi yang dimilikinya. Iqbal selalu tampil dengan optimisme yang luar biasa bahwa kegemilangan masa lalu bukanlah sesuatu yang mustahil untuk dicapai kembali pada masa yang akan datang.

\section{DAFTAR KEPUSTAKAAN}

Azra, Azyumardi, Jaringan Ulama Timur Tengah dan Nusantara Abad 17 dan 18. Bandung: Mizan, 1992

Al-Nadwi, Abu Hasan Ali al-Husni, The Glory of Iqbal, diterjemahkan oleh Suyitno Percikan Kegeniusan Iqbal, Jakarta: Integrita Press, 1985

C.A. Qadir, Filsafat dan Ilmu Pengetahuan dalam Islam, Jakarta: Yayasan Obor Indonesia, 1998

Danusiri, Epistimologi dalam Tasawuf Iqbal, Yogyakarta: Pustaka Pelajar, 1996

Fauzi, Ihsan Ali dan Nurul Agustina, Sisi Manusiawi Iqbal, Bandung: Mizan, 1992

Hassan, Parveen Feroze, The Political Philosophy of Iqbal, Lahore: Publisher United, 1978

Iqbal, Muhammad, Asrar-I-Khudi, diterjemahkan oleh Bahrum Rangkuti Rahasia-Rahasia Pribadi, Jakarta: Bulan Bintang, 1976 , Javid Nameh (Kitab Keabadian), Jakarta: Pustaka Panji Mas, 1987 , The Reconstruction of Religious Thought in Islam, New Delhi: Kitab Bhavan, 1981.

\section{, The Development of} Methaphysic in Persia, Lahore, 1976 
100 Majalah Ilmu Pengetahuan dan Pemikiran Keagamaan Tajdid,

Vol. 21, No. 1, Juli 2018

K.G. Saiyidain, Iqbals Educational Phylosophy, diterjemahkan oleh MI. Solaeman Percikan Filsafat Pendidikan Iqbal, Jakarta: Bulan Bintang 1985

Khamenei, Sayyid Ali, Iqbal. Filsuf Penyair Kebangkitan Dunia Islam, Jurnal Ulumul Quran, Jakarta: LSAF, 1989.

Langgulung, Hasan, Peralihan Paradigma dalam Pendidikan Islam dan Sains Sosial, Jakarta: Gaya Media Pratama, 2002.

Ma'arif, Ahmad Syafi'i, dkk, Sebuah Pengantar dalam Pendidikan Islam di Indonesia, Yogyakarta: Tiara Wacana, 1991.

Muthahhari, Murtadha, Manusia Sempurna; Pandangan Islam tentang Hakikat Manusia, Jakarta, 2000

Nurdin, Ashraf, Pujangga Iqbal, Singapura: Pustaka Nasional, 1985

Nasution, Harun, Pembaharuan Dalam Islam, Jakarta: Bulan Bintang, 1975

Berbagai Aspek, Jakarta: UI Press, 1975 